\title{
Strategi Pengasuhan PT. Pupuk Indonesia (Persero)
}

\author{
Budi Asikin \\ Program Studi Magister Manajemen Eksekutif, Sekolah Tinggi Manajemen PPM \\ Jl. Menteng Raya No.9, Kb. Sirih, Kec. Menteng, Kota Jakarta Pusat, Jakarta, Indonesia \\ Asikin.budi@gmail.com

\section{Muhammad Arief Rusdi} \\ Program Studi Magister Manajemen Eksekutif, Sekolah Tinggi Manajemen PPM \\ Jl. Menteng Raya No.9, Kb. Sirih, Kec. Menteng, Kota Jakarta Pusat, Jakarta, Indonesia \\ Arief.rusdi@gmail.com \\ Ningky Sasanti Munir* \\ Sekolah Tinggi Manajemen PPM \\ Jl. Menteng Raya No.9, Kb. Sirih, Kec. Menteng, Kota Jakarta Pusat, Jakarta, Indonesia \\ ningkymunir@gmail.com
}

Diterima: 09-02-2021

Disetujui: 16-06-2021

Dipublikasi: 30-06-2021

\begin{abstract}
ABSTRAK
Sebagai sebuah entitas bisnis besar yang telah memiliki banyak anak perusahaan, PT Pupuk Indonesia (Persero) dituntut untuk menjalankan sistem tata kelola perusahaan secara profesional berdasarkan prinsip komersial yang kuat, dalam artian mampu memberikan nilai tambah, manfaat maupun tingkat keuntungan yang maksimal kepada para pemegang saham dan pemangku kepentingan yang ada. Oleh sebab itu PT Pupuk Indonesia (Persero) perlu melakukan analisis yang mendalam terhadap implementasi strategi pengelolaan anak-anak perusahaannya untuk mengetahui bagaimana tingkat kesesuaian antara karakteristik induk dengan anak-anak perusahaannya. Dengan demikian perusahaan dapat mengembangkan strategi pengasuhan (parenting strategy) yang sesuai, efektif dan akan semakin meningkatkan nilai serta daya saing perusahaan secara keseluruhan. Penelitian ini merupakan penelitian terapan dengan pendekatan deskriptif kualitatif yang menggunakan Corporate Parenting Framework dari Campbell dkk. (1995). Data diperoleh melalui wawancara, observasi, dan studi dokumen yang relevan. Hasil studi menunjukkan bahwa anak perusahaan yang bergerak di bisnis utama bidang industri pupuk dan bahan kimia berada di kategori Heartland Business. Anak perusahaan yang bergerak di bisnis penunjang bidang industri, perdagangan dan jasa energi, bidang pelayaran dan pengangkutan laut dan bidang industri dan perdagangan pertanian berada di kategori Edge of Heartland, sedangkan untuk anak perusahaan yang bergerak di bidang jasa EPC dan bidang perdagangan dan jasa umum posisinya berada di area Alien Territory. Maka gaya pengasuhan perusahaan induk yang cocok untuk mengasuh anak perusahaan yang masuk dalam kategori Heartland Business adalah gabungan dari corporate development dan linkage influence; untuk anak perusahaan yang masuk dalam area Edge of Heartland adalah stand alone influence; sementara untuk anak perusahaan yang masuk dalam area Alien Territory adalah linkage influence
\end{abstract}

Kata Kunci:

Strategi pengasuhan; Gaya pengasuhan; Kesesuaian pengasuhan; Industri pupuk

\section{ABSTRACT}

As a large business entity that already has many subsidiaries, PT Pupuk Indonesia (Persero) is required to carry out a professional corporate governance system based on strong commercial principles, in the sense that it is able to provide added value, benefits and maximum profit levels to shareholders and existing stakeholders. Therefore, PT Pupuk Indonesia (Persero) needs to carry out an in-depth analysis of the implementation of the management strategy of its subsidiaries to determine the level of compatibility between the characteristics of the parent and its 
subsidiaries. Thus the company can develop a parenting strategy that is appropriate, effective and will further increase the value and competitiveness of the company as a whole. This research is an applied research with a qualitative descriptive approach using the Corporate Parenting Framework from Campbell et al. (1995). Data obtained through interviews, observation, and study of relevant documents. The study shows that the subsidiaries engaged in the main business of the fertilizer and chemical industry are in the Heartland Business category. Subsidiaries engaged in supporting businesses in the industry, trade and energy services sector, shipping and sea transportation and agricultural industry and trade are in the Edge of Heartland category. For subsidiaries engaged in EPC services and trading and general services the position is in the area of the Alien Territory. So the parenting style of a parent company that is suitable for parenting for a subsidiary that falls into the Heartland Business category is a combination of corporate development and linkage influence; for a subsidiary that is part of the Edge of Heartland area, is stand alone influence. Meanwhile, for subsidiaries that are included in the Alien Territory area, the parenting style is linkage influence.

Keywords:

Parenting strategy; Parenting style; Parenting fit; Fertilizer industry 


\section{PENDAHULUAN}

PT Pupuk Indonesia (Persero) atau PI merupakan induk perusahaan (Holding Company) yang membawahkan 10 anak perusahaan yang bergerak dibidang Industri Pupuk dan Bahan Kimia, EPC (Engineering Procurement and Constructions), Perdagangan Umum dan Jasa, Perindustrian dan Perdagangan Bidang Pertanian, Industri Perdagangan dan Jasa Energi, Pelayaran dan Jasa Angkutan Laut. Kesepuluh perusahaan tersebut adalah PT Pupuk Kalimantan Timur (PKT), PT Petrokimia Gresik (PKG), PT Pupuk Kujang (PKC), PT Pupuk Iskandar Muda (PIM), PT Pupuk Sriwijaya Palembang (PSP), PT Mega Eltra (ME), PT Rekayasa Industri (Rekind), PT Pupuk Indonesia Logistik (PLOG), PT Pupuk Indonesia Pangan (PIP), dan PT Pupuk Indonesia Energi (PIE).

Menurut Laporan Tahunan PT Pupuk Indonesia (Persero) tahun 2018, PI mengalami tantangan bisnis dari lingkungan eksternal, antara lain: Harga produk yaitu Amoniak dan Urea tidak stabil dan terus turun, Harga gas domestik relatif tinggi dibandingkan harga internasional menyebabkan HPP (Harga Pokok Penjualan) tinggi sehingga tidak dapat bersaing. Pasokan Urea dunia over supply dan diperkirakan akan berlanjut sampai tahun 2020. Dari lingkungan internal juga terdapat isu stratejik yang mengganggu, yaitu beberapa pabrik pupuk sudah tua dan boros, dilihat dari konsumsi gas bumi yang relatif tinggi dibandingkan pabrik sejenis di dunia. Masih ditambah dengan adanya piutang subsidi pemerintah yang akhirnya membatasi kemampuan keuangan PI untuk mendukung program revitalisasi pabrik.

Indikator dan ukuran tingkat kesehatan PT Pupuk Indonesia (Persero) mengacu kepada Keputusan Menteri BUMN Nomor Kep-100/MBU/2002 tanggal 4 Juni 2002 tentang Penilaian Tingkat Kesehatan BUMN yang diantaranya mengukur tentang laba dan pertumbuhan aset BUMN. Menurut Bowman \& Herfast (2001), Campbell, dkk. (2014), dan Wheelen, dkk. (2014) berbeda dengan tingkat bisnis, di tingkat korporat perusahaan induk menjalankan strategi tingkat korporat yang terdiri dari strategi arah (directional strategy), strategi portofolio (portfolio strategy), dan strategi pengasuhan (parenting strategy untuk mencapai sasaran-sasaran strategik di tingkat korporat. Untuk menghadapi tantangan eksternal dan internal yang ada, dan memenuhi ukuran kesehatan perusahaan, PI telah memiliki strategi arah dan strategi portofolio bisnis sebagaimana diatur dalam Rencana Jangka Panjang (RJP) 2018-2022 yang telah mendapat pengesahan dari Menteri BUMN selaku Pemegang Saham. PI belum memiliki strategi pengasuhan yang terstruktur, yang dibutuhkan untuk mengendalikan perusahaan-perusahaan anak sehingga secara sinerjik dapat mencapai kinerja kelompok bisnis.

Strategi pengasuhan, menurut Campbell, dkk. (1995, 2014), Goold, dkk. (1998), dan Wheelen, dkk. (2014) ditentukan dengan melihat kesesuaian antara karakteristik pengasuhan induk perusahaan dengan peluang-peluang pengasuhan yang ada di perusahaan-perusahaan anak, dan faktor sukses kritis perusahaan anak di industri dimana mereka beroperasi. Oleh sebab itu studi ini dilakukan untuk merancang strategi pengasuhan PT Pupuk Indonesia (Persero) tahun 2019-2022. Periode yang sedikit berbeda dengan periode RJPP menunjukkan bahwa strategi pengasuhan akan menjadi pelengkap RJPP yang sudah ada. 
Secara rinci studi ini akan menentukan kesesuaian antara peluang pengasuhan yang ada di masing-masing perusahaan anak dengan karakteristik pengasuhan oleh perusahaan induk. Juga akan ditentukan ketidaksesuaian antara faktor-faktor sukses kritis masing-masing perusahaan anak dengan karakteristik pengasuhan oleh perusahaan induk.

Studi ini diharapkan akan memberikan kontribusi akademik bagi aplikasi konsep strategi pengasuhan di kelompok perusahaan di Indonesia. Seperti disampaikan oleh Kruehler dkk. (2018), aplikasi konsep strategi pengasuhan dari Campbell, dkk. (1995) dan Goold, dkk. (1998) masih terbatas karena tidak ada penjelasan mengenai cara melakukan asesmen kesesuaian antara perusahaan induk dengan perusahaan-perusahaan anak di dalam kelompok bisnis.

Menurut Campbel, dkk. (1995, 2014), serta studi yang lebih terkini dari Kim (2018), serta Kishita \& Hayashi (2019) induk perusahaan perlu memastikan terjadinya kreasi nilai melalui pengasuhan (parenting) pada perusahaan-perusahaan anak. Hal ini merupakan hal yang tidak mudah mengingat masing-masing perusahaan anak beroperasi pada wilayah berbeda dengan karakteristik persaingan yang berbeda-beda pula.

Sesuai dengan studi dari Nell (2013), Munir (2017), Toto (2017), serta Kim (2018) induk perusahaan harus dapat mengasuh untuk memberikan manfaat atau parenting advantage, dalam bentuk kreasi nilai yang lebih bagi anak-anak perusahaan dan kelompok bisnisnya secara keseluruhan. Induk perusahaan diharapkan dapat melakukan pengasuhan yang akan membuat kompetensi inti kelompok bisnisnya terus berkembang (Ciabushchi, dkk. 2016) dan selanjutnya kelompok bisnis tersebut dapat terus menciptakan nilai dan bertumbuh dengan menggunakan basis kompetensi inti tersebut (Rawley, dkk., 2018).

Pengasuhan juga dapat berpeluang merusak nilai (value destruction) apabila antara induk dan anak perusahaan tidak ada kesesuaian. Ketidaksesuaian ini dapat terjadi karena tidak adanya kesesuaian antara karakteristik induk perusahaan dengan karakteristik anak-anak perusahaan (Campbell, dkk. 2014). Ketidaksesuaian karakteristik antara induk dengan anak perusahaan akan menyebabkan induk perusahaan tidak dapat melakukan pengasuhan yang bermanfaat bagi pertumbuhan anak perusahaan. Misalnya, anak perusahaan tidak memperoleh manfaat dari keunggulan kompetensi yang dimiliki induk (Afza, dkk. 2008) atau anak perusahaan lainnya, atau anak perusahaan tidak dapat memanfaatkan sumberdaya bersama yang dimiliki oleh kelompok bisnisnya (Basu, 2010), dan lain sebagainya.

Untuk mengembangkan strategi pengasuhan, Campbell, dkk. (1995, 2014) dan Goold, dkk. (1998) mengembangkan suatu matrix yang dinamakan Matriks Kesesuaian Pengasuhan (Parenting Fit Matrix) (Gambar 1). Melalui matriks ini, kelompok bisnis dapat memetakan posisi setiap perusahaan anak menurut dua hubungan kesesuaian. Di sumbu X dipetakan kesesuaian antara peluang pengasuhan yang ada pada perusahaan-perusahaan anak dengan karakteristik pengasuhan perusahaan induk. Sementara di sumbu Y dipetakan ketidaksesuaian antara faktor-faktor sukses kritis perusahaan anak dengan karakteristik pengasuhan perusahaan induk. 


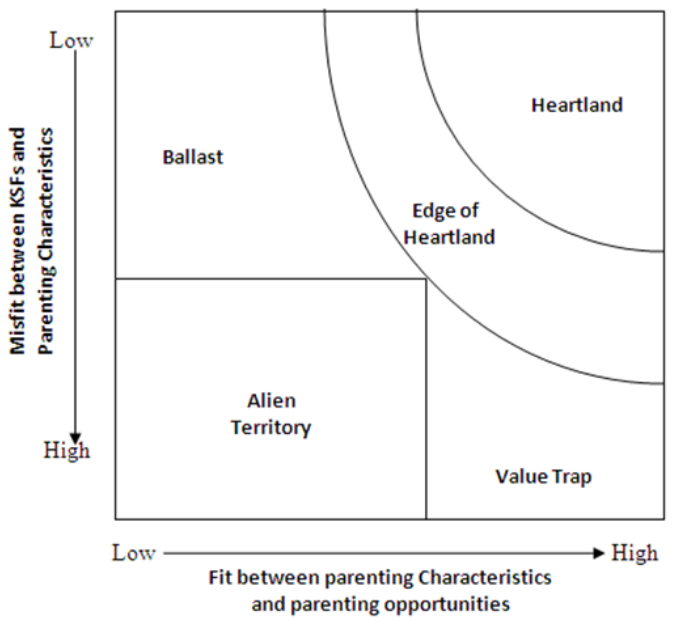

Gambar 1. Matriks Kesesuaian Pengasuhan (Parenting-Fit Matrix) Sumber: Campbell, dkk. (1995, 2014)

Hasil pemetaan akan menunjukkan posisi masing-masing perusahaan di lima area atau kelompok perusahaan, yaitu kelompok heartland, edge of heartland, ballast, value trap, dan alien territory (Campbell, dkk., 1995, 2014). Selanjutnya menurut Goold, dkk (1998), juga Nell \& Ambos (2013), Ciabuschi dkk. (2016) dan Rawley, dkk. (2018) terdapat empat kemungkinan perusahaan induk melakukan kreasi nilai dalam perusahaan multibisnis.

Pertama adalah stand alone influence, dimana perusahaan induk mempengaruhi masing-masing strategi bisnis perusahaan anak dan keterlibatan langsung dalam setiap pengambilan keputusan penting dan strategis. Jadi kreasi nilai disini terjadi karena perusahaan induk menerapkan pengendalian yang ketat atas kinerja perusahaan-perusahaan anak yang diberi tanggung jawab atas laba.

Kedua adalah linkage influence, dimana perusahaan induk mempengaruhi seluruh perusahaan anak melalui pengendalian ketat atas hubungan antar unit bisnis. Seperti ditegaskan oleh Porter (1998) kreasi nilai dalam linkage influence terjadi karena perusahaan induk sangat memperhatikan sinergi antar perusahaan dalam perusahaan multibisnisnya agar nilai yang diciptakan tidak hanya sekedar hasil penjumlahan nilai dari perusahaan- perusahaan anak, melainkan lebih dari itu.

Ketiga adalah, control function and services, dimana kreasi nilai dalam perusahaan multibisnis dilakukan oleh perusahaan induk melalui pemusatan berbagai kegiatan fungsional dan pelayanan (centralised functions and services). Menurut Collis, dkk. (2012) sebenarnya pengelolaan seperti ini sangat berisiko karena dapat menyebabkan tingginya biaya overhead, memperlambat pengambilan keputusan, dan dukungan yang diberikan tidak memadai (unresponsive support).

Terakhir adalah corporate development, dimana perusahaan induk melakukan kreasi nilai melalui penetapan portofolio bisnis. Induk perusahaan melakukan diversifikasi dengan salah satu cara mengakuisisi bisnis baru dengan harga relatif murah, dengan harapan akan membuat mereka menjadi lebih kompetitif, serta terciptanya modal baru yang akan mendukung potensi pertumbuhan di masa yang akan datang. 


\section{METODE RISET}

Studi ini merupakan studi kualitatif dengan pendekatan deskriptif kualitatif. Tidak ada pengembangan hipotesis, tujuan studi adalah untuk menjawab permasalahan yang dihadapi oleh eksekutif di perusahaan melalui eksplorasi dan eksplanasi fenomena yang ada di perusahaan (Sekaran \& Bougie, 2016). Data diperoleh melalui dua cara: data primer diperoleh melalui wawancara dengan direksi PI dan direksi perusahaan-perusahaan anak, sedangkan data sekunder diperoleh terutama dari laporan-laporan internal perusahaan seperti rencana jangka panjang dan laporan tahunan manajemen dari perusahaan-perusahaan anak.

Mengikuti Kruehler, dkk. (2012) dan Pidun, dkk. (2019) terdapat empat kegiatan utama untuk menyusun matriks kesesuaian pengasuhan. Pertama adalah mengidentifikasikan faktor-faktor sukses kritis dari perusahaan-perusahaan anak. Faktor-faktor ini seluruhnya dikelompokkan menurut kompetensi inti perusahaan (Munir, 2017). Kelompok bisnis yang sangat terdiversifikasi (konglomerasi) akan memiliki banyak faktor sukses kritis, kaena setiap perusahaan anak mungkin memiliki kompetensi inti berbeda dan beroperasi di industri yang berbeda satu dengan yang lain (Munir, 2017, Rawley, dkk., 2018).

Kedua dilakukan identifikasi peluang-peluang pengasuhan melalui analisis kinerja perusahaanperusahaan anak. Langkah pertama dan kedua ini akan membuat peneliti memahami karakteristik masing-masing perusahaan anak, dan merupakan langkah yang penting bila kelompok bisnis mempunyai banyak perusahaan anak.

Ketiga dilakukan analisis mengenai karakteristik perusahaan induk. Menurut Campbell, dkk. (1995, 2014) dan Goold, dkk. (1998) karakteristik perusahaan induk dapat dikelompokkan dalam lima kategori, yaitu: (1) The mental maps that guide parent managers, atau nilai-nilai dan kebiasaan yang memandu para eksekutif di induk perusahaan mengambil keputusan dan bertindak; (2) The corporate structure, management system and process, yaitu banyaknya tingkatan dalam suatu hirarki, keberadaan suatu matrik, proses penunjukan manajemen, sistem perekrutan SDM, proses perencanaan dan pembelajaran, struktur pembuatan keputusan strategis dan sistem harga transfer adalah faktor penting yang memungkinkan untuk menciptakan nilai; (3) The central function, service, and resource, yaitu keunggulan sumber daya, reputasi atau citra merek dan hubungan baik dengan pembuat regulasi di tingkat pemerintah/negara, baik nasional maupun internasional. (4) The decentralization contract between parents and business, yaitu batasan otoritas dan pembagian tugas antara induk perusahaan dan perusahaan anak. Terakhir (5) The nature, experience and skill of manager in the parent organization, yaitu keunggulan kompetensi para eksekutif di induk perusahaan, karena banyak korporat mampu menciptakan nilai bagi bisnisnya karena dominasi manajer dengan kapabilitas dan kompetensi yang kuat. 


\section{HASIL PENELITIAN DAN PEMBAHASAN}

Dari wawancara dengan jajaran direksi di PI dan perusahaan-perusahaan anak, diperoleh tujuh karakteristik pengasuhan perusahaan induk, yaitu: (1) Pendanaan Korporasi dilakukan oleh PI selaku induk perusahaan, hal ini merupakan bagian dari the central function services and resources; (2) Penetapan Investasi \& Pengembangan serta Riset dilakukan oleh PI selaku induk perusahaan, dalam bentuk pedoman investasi untuk anak-anak perusahaan, dan mekanisme atau prosedur yang mengacu kepada anggaran dasar perusahaan, hal ini merupakan bagian dari the corporate structure, management systems, and processes; (3) Pengembangan Sumber Daya Manusia (SDM), PI mengembangkan sistem manajemen SDM berbasis kompetensi, sehingga mulai dari tahap rekrutmen hingga evaluasi kinerja pegawai dilandaskan pada pemenuhan kompetensi SDM dan kebutuhan personil diseluruh unit kerja, juga mengelola sistem manajemen pengetahuan korporat, PI juga memastikan bahwa nilai-nilai perusahaan yang menjadi dasar budaya perusahaan diterapkan diseluruh perusahaan anak. Hal ini merupakan bagian dari the corporate structure, management systems, and processes, the nature, experience, and skill of managers in the parent organization (people and skills), the parent's mental maps that guide parent managers; (4) Pengaturan Pemasaran PSO \& Non PSO, PI mendapat penugasan dari pemerintah melalui Kementerian Pertanian yaitu pengadaan dan penyaluran pupuk bersubsidi atau disebut Public Service Obligation (PSO), hal itu kemudian dituangkan dalam supply agreement antara Kementerian Pertanian dengan PT Pupuk Indonesia (Persero). Selanjutnya ditindaklanjuti dengan membuat perjanjian antara PI dengan anak perusahaan produsen pupuk. Untuk pemasaran Non PSO, masing-masing anak perusahaan dapat melakukan proses penjualan atau distribusi masing-masing namun dalam prakteknya diatur dengan memperhatikan less cost distribution, efisiensi dan efektivitas untuk mencapai kinerja perusahaan secara konsolidasi, serta agar tidak terjadi kompetisi diantara anak perusahaan. Hal ini merupakan bagian dari the decentralization contract between parents and business; (5) Sinergi Pengadaan dan Logistik, PI mengeluarkan berupa pedoman pengadaan barang dan jasa untuk Pupuk Indonesia Group dengan merujuk pada Peraturan Menteri BUMN. Pedoman ini mengatur mengenai hal apa saja yang bisa dilakukan oleh anak perusahaan dan barang atau jasa apa saja yang dapat dilakukan bersama-sama. Selain itu ditentukan juga sinergi dibidang logistik dalam rangka memperkuat struktur usaha anak perusahaan, PT Pupuk Indonesia Logistik. Sinergi Pengadaan dan Logistik ini merupakan bagian dari the central function services and resources; (6) Perencanaan Produksi dan Operasional, PI meminta setiap perusahaan anak untuk rencana kerja, anggaran dan program (RKAP) masing-masing, yang kemudian dievaluasi oleh PI. Selain itu setiap bulan dilakukan monitoring operasi, dimana setiap anak perusahaan melaporkan kinerja produksinya dengan mengacu pada rencana produksi yang tertuang dalam RKAP serta indikator-indikator kinerja kunci setiap perusahaan anak. Hal ini merupakan bagian dari the corporate structure, the nature, experience, and skill of managers in the parent organization (people and skills). (7) Koordinasi, Negosiasi dengan Pemasok Gas, posisi gas dari sisi kontrak bukan di PI tetapi di masing-masing anak perusahaan namun demikian PI selaku induk perusahaan mendampingi dalam proses rapat teknis, memformulasikan harga 
gas, mengevaluasi dan ikut mendorong/memfasilitasi melalui Kementerian BUMN bilamana ada permasalahan. Hal ini merupakan bagian dari the decentralization contract between parents and business.

Selanjutnya diidentifikasikan faktor-faktor sukses kritis dan peluang-peluang pengasuhan setiap perusahaan anak. Setiap faktor tersebut diberi bobot kepentingannya dan dinilai seberapa sesuai atau tidak sesuainya kedua kelompok faktor tersebut dengan karakteristik pengasuhan perusahaan induk. Nilai 5 menunjukkan kesesuaian yang tinggi antara peluang pengasuhan dan karakteristik perusahaan induk, sementara nilai yang berarti ketidaksesuaian antara faktor sukses kritis dengan karakteristik perusahaan induk. Tabel 1 hingga 10 menunjukkan hasil perhitungan kesesuaian/ketidaksesuaian faktor perusahaan anak dan perusahaan induk.

Tabel 1. Perhitungan Kesesuaian/Ketidaksesuaian Karakteristik Pengasuhan dengan Faktor Sukses Kritis dan Peluang Pengasuhan PT. Petrokimia Gresik

\begin{tabular}{|c|c|c|c|c|c|c|c|c|c|c|c|c|}
\hline & \multirow[b]{2}{*}{ Keterangan } & \multicolumn{11}{|c|}{ Karakteristik Pengasuhan } \\
\hline & & 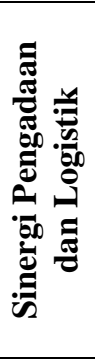 & 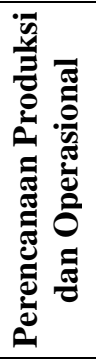 & 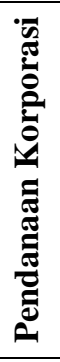 & 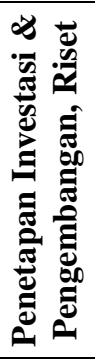 & 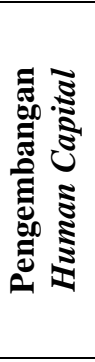 & 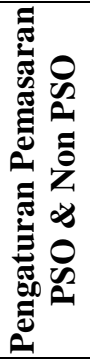 & 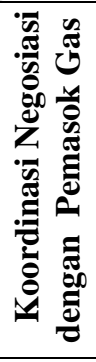 & 蔦 & 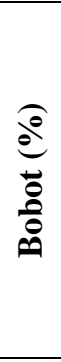 & 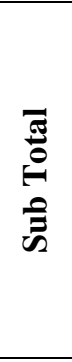 & 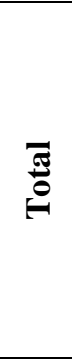 \\
\hline \multirow{6}{*}{ 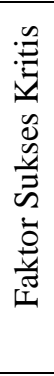 } & Harga Pokok & & & & & & & & & & & \multirow{6}{*}{34,3} \\
\hline & $\begin{array}{l}\text { Produksi (HPP) } \\
\text { vang kompetitif }\end{array}$ & 5 & 5 & 5 & 4 & 5 & 5 & 4 & 33 & 20 & 6,8 & \\
\hline & $\begin{array}{l}\text { Kontrak dengan } \\
\text { pemerintah (PSO) }\end{array}$ & 5 & 5 & 5 & 5 & 5 & 5 & 5 & 35 & 20 & 7,0 & \\
\hline & $\begin{array}{l}\text { Penjualan dan } \\
\text { layanan (Non PSO) }\end{array}$ & 5 & 5 & 5 & 5 & 5 & 5 & 5 & 35 & 30 & 10,5 & \\
\hline & Kompetensi SDM & 4 & 5 & 5 & 5 & 5 & 5 & 5 & 34 & 30 & 10,2 & \\
\hline & & & & & & & & & & 100 & & \\
\hline \multirow{6}{*}{ 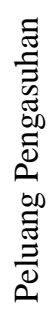 } & Management & 5 & 5 & 5 & 5 & 5 & 5 & 5 & 35 & 25 & 8,8 & \multirow{6}{*}{35,0} \\
\hline & Bisnis Definition & 5 & 5 & 5 & 5 & 5 & 5 & 5 & 35 & 15 & 5,3 & \\
\hline & Linkagers & 5 & 5 & 5 & 5 & 5 & 5 & 5 & 35 & 20 & 7,0 & \\
\hline & External Relation & 5 & 5 & 5 & 5 & 5 & 5 & 5 & 35 & 15 & 5,3 & \\
\hline & $\begin{array}{l}\text { Common } \\
\text { Capabilities }\end{array}$ & 5 & 5 & 5 & 5 & 5 & 5 & 5 & 35 & 15 & 5,3 & \\
\hline & Predictible Error & 5 & 5 & 5 & 5 & 5 & 5 & 5 & 35 & 10 & 3,5 & \\
\hline
\end{tabular}

Sumber: Hasil pengolahan data oleh peneliti 
Asikin, B., Rusdi, M.A. \& Munir, N.S.. (2021). Strategi Pengasuhan PT. Pupuk Indonesia .....

Tabel 2. Perhitungan Kesesuaian/Ketidaksesuaian Karakteristik Pengasuhan dengan Faktor Sukses Kritis dan Peluang Pengasuhan PT. Pupuk Kujang

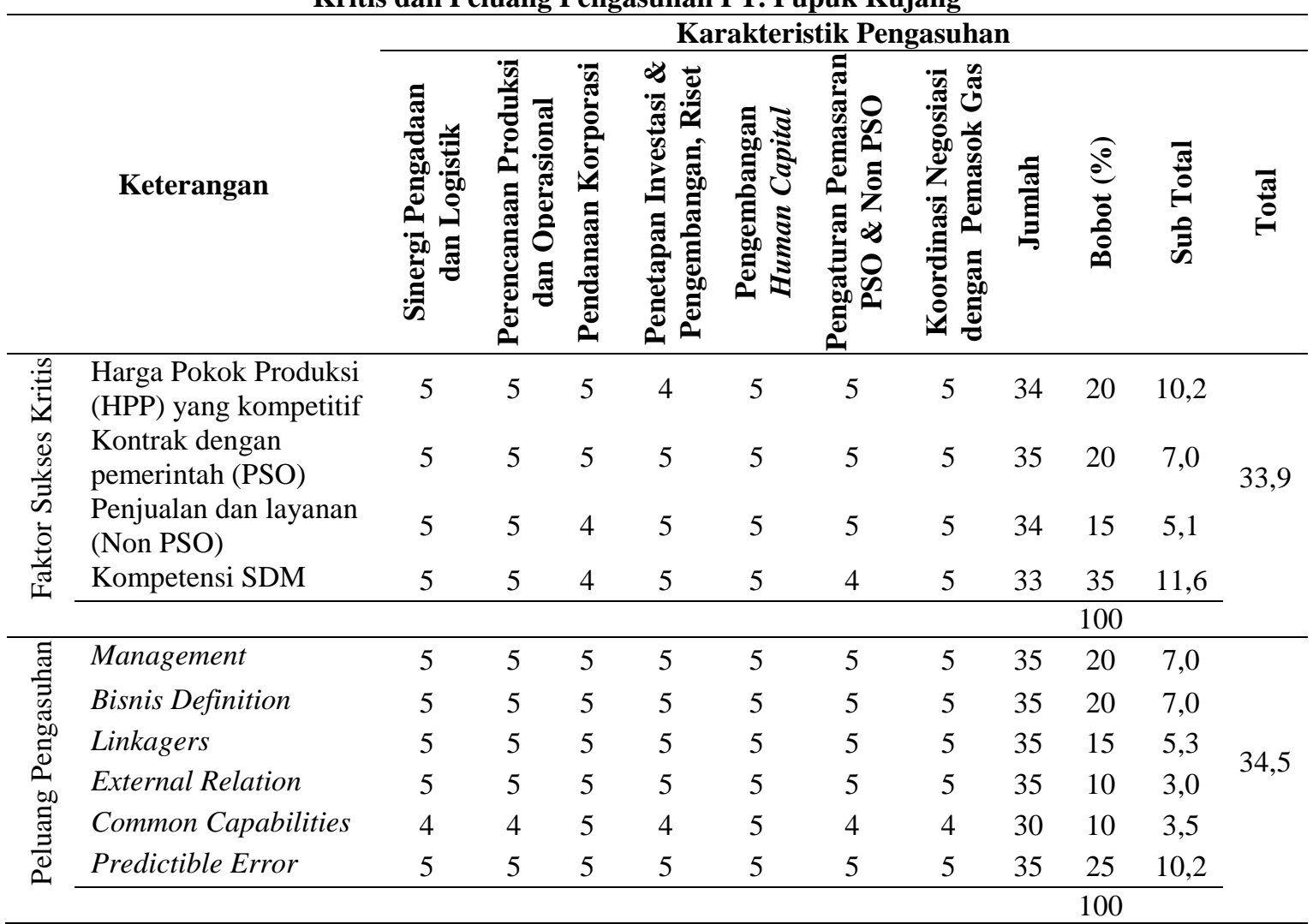

Sumber: Hasil pengolahan data oleh peneliti

Tabel 3. Perhitungan Kesesuaian/Ketidaksesuaian Karakteristik Pengasuhan dengan Faktor Sukses Kritis dan Peluang Pengasuhan PT. Pupuk Kalimantan Timur Karakteristik Pengasuhan

\begin{tabular}{|c|c|c|c|c|c|c|c|c|c|c|c|c|}
\hline & \multirow[b]{2}{*}{ Keterangan } & \multicolumn{11}{|c|}{ Karakteristik Pengasuhan } \\
\hline & & 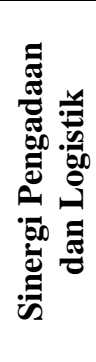 & 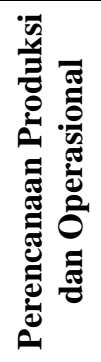 & 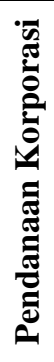 & 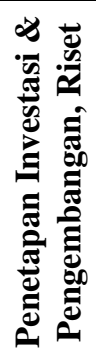 & 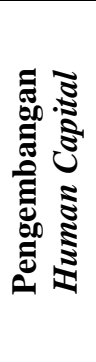 & 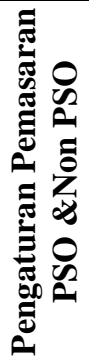 & 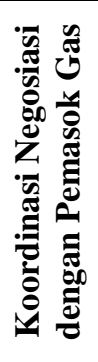 & $\underset{\Xi}{\underline{\Xi}}$ & 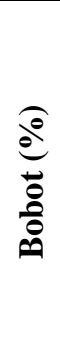 & $\begin{array}{l}\overline{\tilde{J}} \\
\overrightarrow{0} \\
\vec{E} \\
\vec{E}\end{array}$ & $\stackrel{\vec{T}}{\stackrel{0}{\theta}}$ \\
\hline \multirow{5}{*}{ 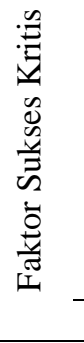 } & $\begin{array}{l}\text { Harga Pokok Produksi } \\
\text { (HPP) yang kompetitif }\end{array}$ & 5 & 5 & 5 & 5 & 5 & 4 & 5 & 34 & 30 & 10,2 & \multirow{5}{*}{34,4} \\
\hline & $\begin{array}{l}\text { Kontrak dengan } \\
\text { pemerintah (PSO) }\end{array}$ & 5 & 5 & 5 & 5 & 5 & 5 & 5 & 35 & 20 & 7,0 & \\
\hline & $\begin{array}{l}\text { Penjualan dan layanan } \\
\text { (Non PSO) }\end{array}$ & 5 & 5 & 5 & 5 & 5 & 5 & 5 & 35 & 15 & 5,3 & \\
\hline & \multirow[t]{2}{*}{ Kompetensi SDM } & 5 & 5 & 4 & 5 & 5 & 5 & 5 & 34 & 35 & 11,9 & \\
\hline & & & & & & & & \multicolumn{4}{|c|}{100} & \\
\hline \multirow{6}{*}{ 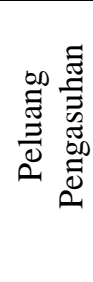 } & Management & 5 & 5 & 5 & 5 & 5 & 5 & 5 & 35 & 20 & 7,0 & \multirow{6}{*}{35,0} \\
\hline & Bisnis Definition & 5 & 5 & 5 & 5 & 5 & 5 & 5 & 35 & 20 & 7,0 & \\
\hline & Linkagers & 5 & 5 & 5 & 5 & 5 & 5 & 5 & 35 & 15 & 5,3 & \\
\hline & External Relation & 5 & 5 & 5 & 5 & 5 & 5 & 5 & 35 & 10 & 3,5 & \\
\hline & Common Capabilities & 5 & 5 & 5 & 5 & 5 & 5 & 5 & 35 & 10 & 3,5 & \\
\hline & Predictible Error & 5 & 5 & 5 & 5 & 5 & 5 & 5 & 35 & 30 & 10,2 & \\
\hline
\end{tabular}

Sumber: Hasil pengolahan data oleh peneliti 
Tabel 4. Perhitungan Kesesuaian/Ketidaksesuaian Karakteristik Pengasuhan dengan Faktor Sukses Kritis dan Peluang Pengasuhan PT. Pupuk Iskandar Muda

\section{Karakteristik Pengasuhan}

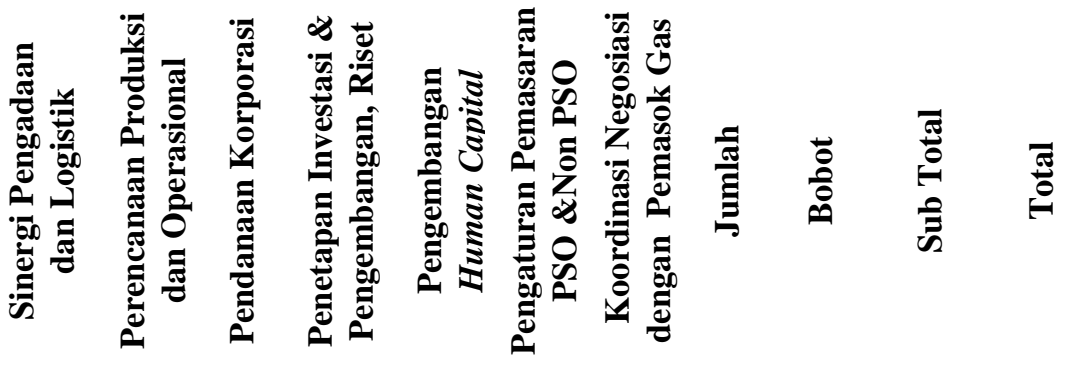

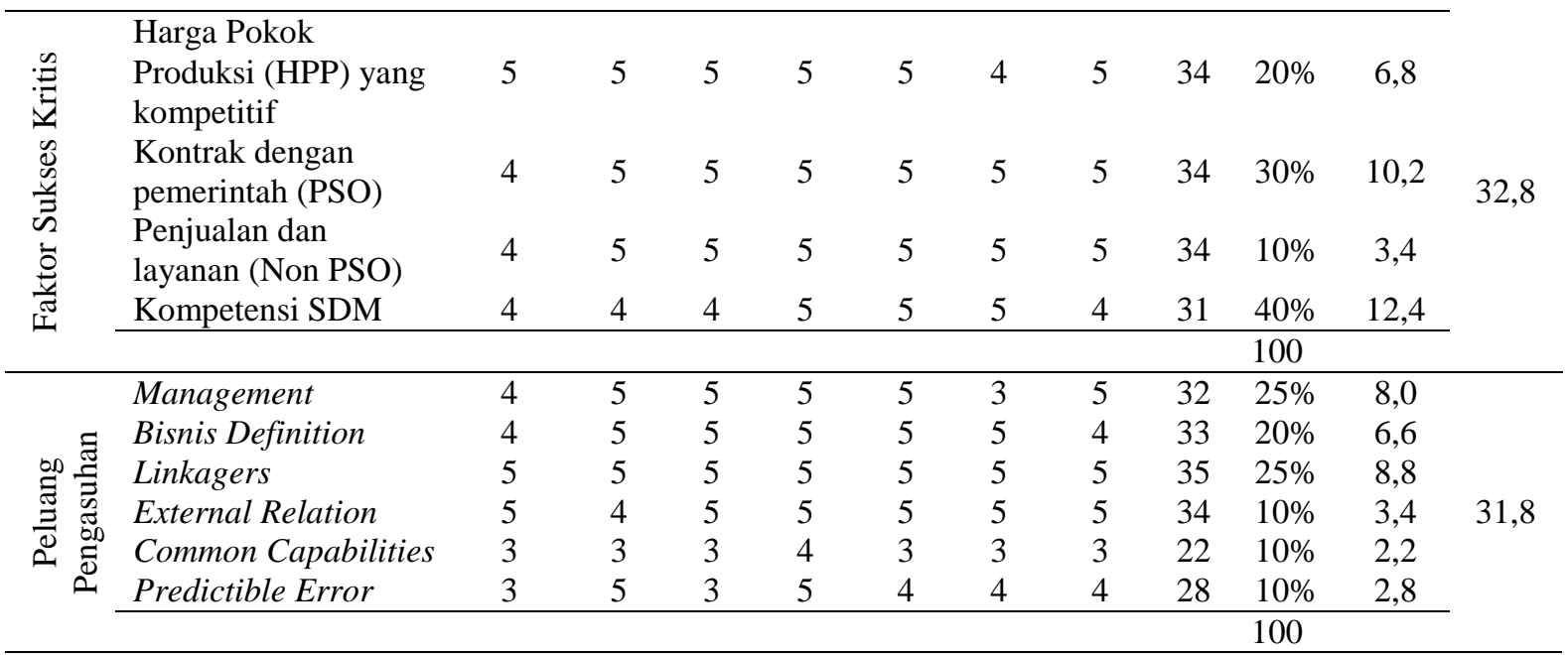

Sumber: Hasil pengolahan data oleh peneliti

Tabel 5. Perhitungan Kesesuaian/Ketidaksesuaian Karakteristik Pengasuhan dengan Faktor Sukses Kritis dan Peluang Pengasuhan PT. Pupuk Sriwijaya Karakteristik Pengasuhan

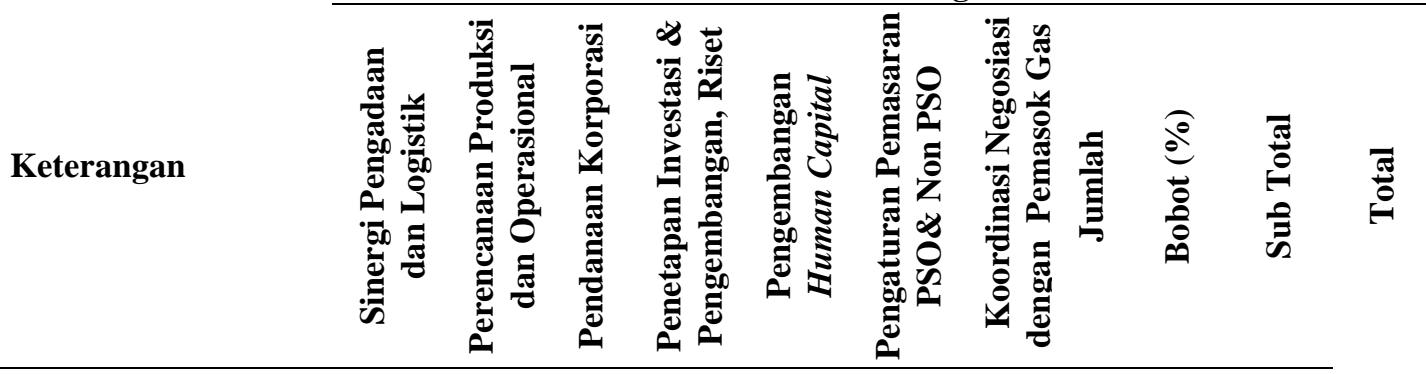

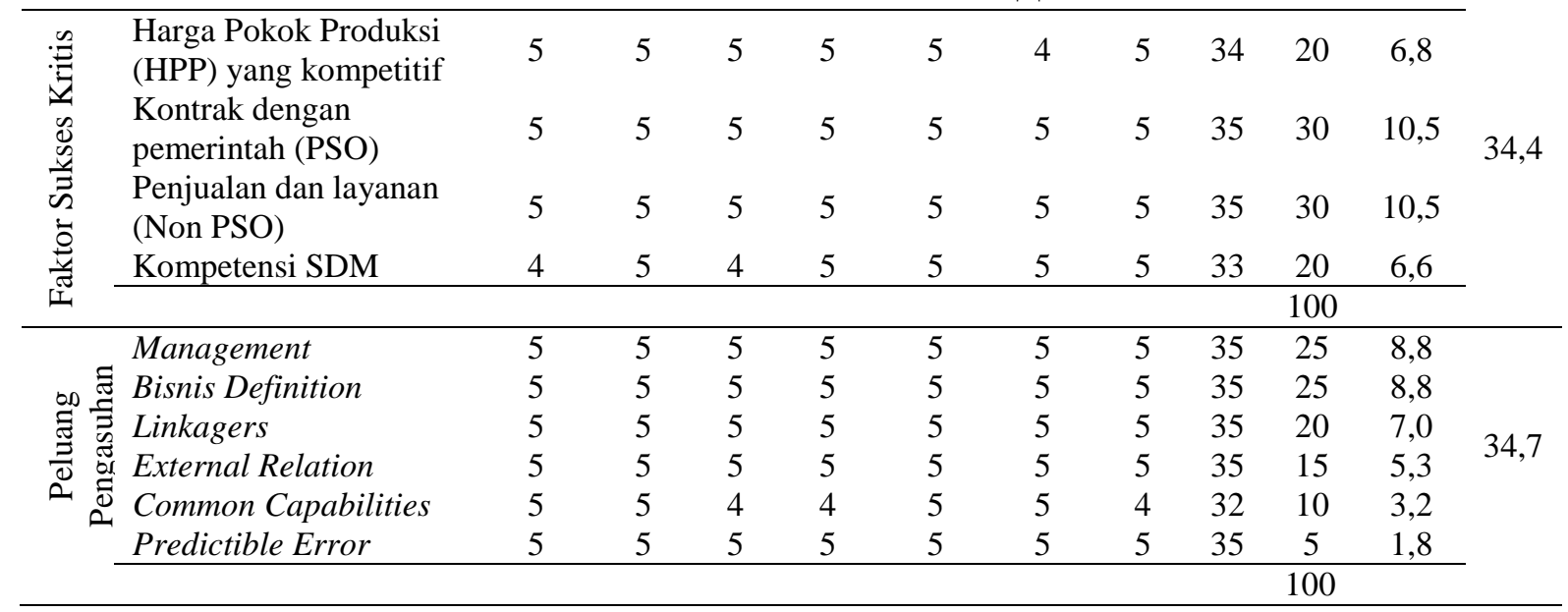


Asikin, B., Rusdi, M.A. \& Munir, N.S.. (2021). Strategi Pengasuhan PT. Pupuk Indonesia .....

Tabel 6. Perhitungan Kesesuaian/Ketidaksesuaian Karakteristik Pengasuhan dengan Faktor Sukses Kritis dan Peluang Pengasuhan PT. Rekayasa Industri

\begin{tabular}{|c|c|c|c|c|c|c|c|c|c|c|c|c|}
\hline \multirow{2}{*}{\multicolumn{2}{|c|}{ Keterangan }} & \multicolumn{11}{|c|}{ Parenting Characteristics } \\
\hline & & 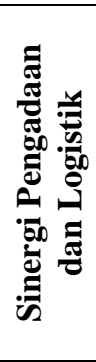 & 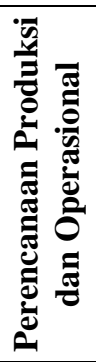 & 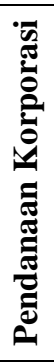 & 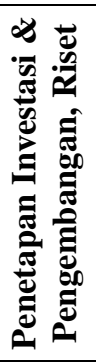 & 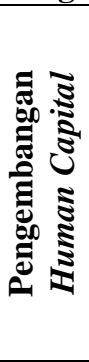 & 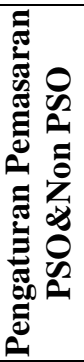 & 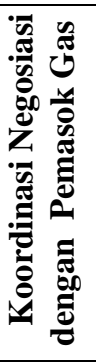 & 蔦 & $\begin{array}{l}\stackrel{0}{0} \\
\stackrel{0}{0} \\
\frac{0}{0}\end{array}$ & 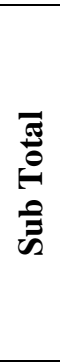 & $\stackrel{\overrightarrow{0}}{\stackrel{0}{\theta}}$ \\
\hline \multirow{6}{*}{ 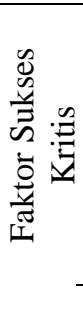 } & Kompetensi SDM & 2 & 1 & 4 & 5 & 5 & 1 & 1 & 19 & 30 & 5,7 & \multirow{6}{*}{18,3} \\
\hline & Outsourching Partnership & 2 & 2 & 3 & 2 & 2 & 1 & 1 & 13 & 15 & 2,0 & \\
\hline & $\begin{array}{l}\text { Supply Chain } \\
\text { Management }\end{array}$ & 4 & 1 & 3 & 2 & 4 & 1 & 1 & 16 & 20 & 3,2 & \\
\hline & $\begin{array}{l}\text { Quality of } \\
\text { Product/Services }\end{array}$ & 3 & 3 & 3 & 4 & 5 & 1 & 1 & 20 & 20 & 4,0 & \\
\hline & Sinergi & 3 & 3 & 5 & 5 & 5 & 1 & 1 & 23 & 15 & 3,5 & \\
\hline & & & & & & & & & & 100 & & \\
\hline \multirow{4}{*}{ 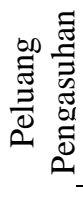 } & Bisnis Definition & 3 & 2 & 5 & 5 & 4 & 1 & 1 & 21 & 20 & 4,2 & \multirow{4}{*}{18,7} \\
\hline & Linkagers & 4 & 2 & 5 & 4 & 4 & 1 & 1 & 21 & 25 & 5,3 & \\
\hline & External Relation & 2 & 1 & 4 & 4 & 3 & 1 & 1 & 16 & 35 & 5,6 & \\
\hline & Major Decision & 2 & 1 & 5 & 4 & 4 & 1 & 1 & 18 & 20 & 3,6 & \\
\hline
\end{tabular}

Sumber: Hasil pengolahan data oleh peneliti

Tabel 7. Perhitungan Kesesuaian/Ketidaksesuaian Karakteristik Pengasuhan dengan Faktor Sukses Kritis dan Peluang Pengasuhan PT. Mega Eltra

\begin{tabular}{|c|c|c|c|c|c|c|c|c|c|c|c|c|}
\hline \multirow{2}{*}{\multicolumn{2}{|c|}{ Keterangan }} & \multicolumn{11}{|c|}{ Parenting Characteristics } \\
\hline & & 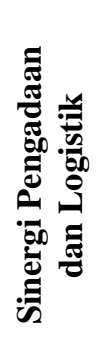 & 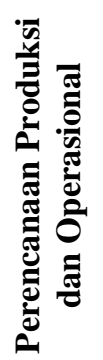 & 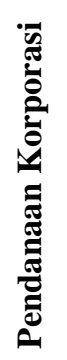 & 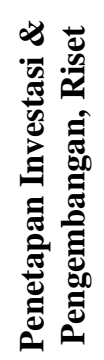 & 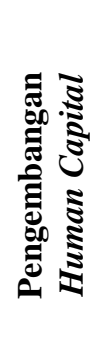 & 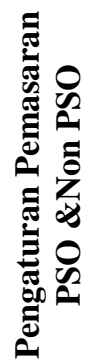 & 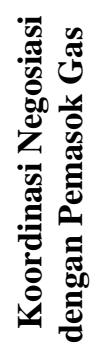 & $\begin{array}{l}\text { 兘 } \\
\text { हू }\end{array}$ & $\begin{array}{l}\stackrel{8}{8} \\
\stackrel{0}{0} \\
\stackrel{0}{0}\end{array}$ & 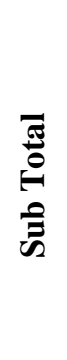 & $\begin{array}{l}\bar{\sigma} \\
0 \\
\theta\end{array}$ \\
\hline \multirow{5}{*}{ 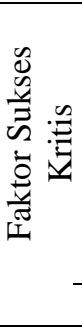 } & $\begin{array}{l}\text { Harga yang } \\
\text { kompetitif }\end{array}$ & 5 & 2 & 4 & 2 & 4 & 2 & 1 & 20 & 30 & 6,0 & \multirow{5}{*}{17,8} \\
\hline & Sinergi & 5 & 1 & 5 & 3 & 5 & 3 & 1 & 23 & 20 & 4,6 & \\
\hline & $\begin{array}{l}\text { Kompetensi } \\
\text { SDM }\end{array}$ & 3 & 1 & 2 & 2 & 5 & 1 & 1 & 15 & 35 & 5,3 & \\
\hline & $\begin{array}{l}\text { Supply Chain } \\
\text { Management }\end{array}$ & 2 & 1 & 2 & 2 & 4 & 1 & 1 & 13 & 15 & 2,0 & \\
\hline & & & & & & & & \multicolumn{4}{|c|}{100} & \\
\hline \multirow{6}{*}{ 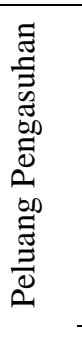 } & \multirow{6}{*}{$\begin{array}{l}\text { Management } \\
\text { Bisnis } \\
\text { Definition } \\
\text { Linkagers } \\
\text { External } \\
\text { Relation } \\
\text { Preditible } \\
\text { Error } \\
\end{array}$} & 4 & 1 & 2 & 4 & 5 & 2 & 1 & 19 & 30 & 5,7 & \multirow{6}{*}{17,6} \\
\hline & & 3 & 1 & 4 & 4 & 5 & 2 & 1 & 20 & 20 & 4,0 & \\
\hline & & 4 & 1 & 3 & 3 & 2 & 3 & 1 & 17 & 15 & 2,6 & \\
\hline & & 2 & 1 & 3 & 4 & 3 & 1 & 1 & 15 & 25 & 3,8 & \\
\hline & & 3 & 1 & 2 & 4 & 4 & 1 & 1 & 16 & 10 & 1,6 & \\
\hline & & & & & & & & \multicolumn{4}{|c|}{100} & \\
\hline
\end{tabular}


Tabel 8. Perhitungan Kesesuaian/Ketidaksesuaian Karakteristik Pengasuhan dengan Faktor Sukses Kritis dan Peluang Pengasuhan PT. Pupuk Indonesia Logistik

\begin{tabular}{|c|c|c|c|c|c|c|c|c|c|c|c|c|}
\hline \multirow[b]{2}{*}{ 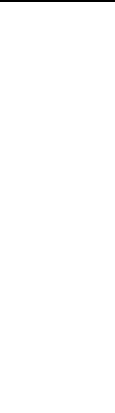 } & \multirow[b]{2}{*}{ Keterangan } & \multicolumn{11}{|c|}{ Karakteristik Pengasuhan } \\
\hline & & 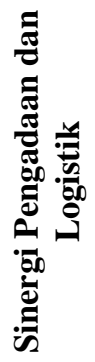 & 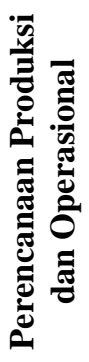 & 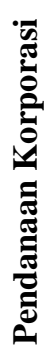 & 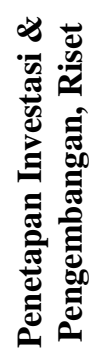 & 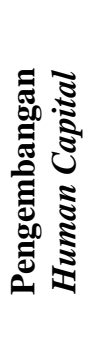 & 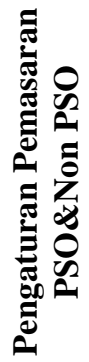 & 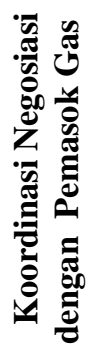 & 疍 & $\underbrace{\frac{8}{8}}_{\frac{8}{8}}$ & 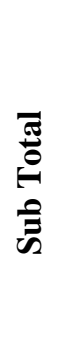 & 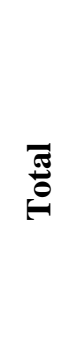 \\
\hline \multirow{5}{*}{ 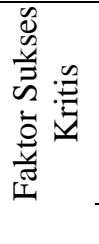 } & $\begin{array}{l}\text { Harga yang } \\
\text { kompetitif }\end{array}$ & 5 & 5 & 4 & 3 & 4 & 2 & 1 & 24 & 35 & 8.4 & \multirow{5}{*}{24.4} \\
\hline & Services & 4 & 4 & 3 & 3 & 4 & 4 & 1 & 23 & 15 & 3.5 & \\
\hline & Sinergi & 5 & 5 & 3 & 3 & 4 & 4 & 1 & 25 & 30 & 7.5 & \\
\hline & Kompetensi SDM & 4 & 5 & 3 & 3 & 5 & 4 & 1 & 25 & 20 & 5 & \\
\hline & & & & & & & & & \multicolumn{3}{|c|}{100} & \\
\hline \multirow{6}{*}{ 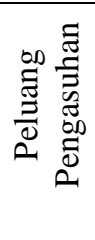 } & Size and Age & 5 & 5 & 4 & 4 & 4 & 3 & 1 & 26 & 15 & 3.9 & \multirow{6}{*}{25.9} \\
\hline & Bisnis Definition & 5 & 4 & 5 & 4 & 5 & 3 & 1 & 27 & 10 & 2.7 & \\
\hline & Linkagers & 5 & 4 & 4 & 4 & 4 & 3 & 1 & 25 & 25 & 6.3 & \\
\hline & External Relation & 5 & 4 & 5 & 4 & 4 & 3 & 1 & 26 & 20 & 5.2 & \\
\hline & Major Decision & 4 & 4 & 5 & 5 & 4 & 3 & 1 & 26 & 30 & 7.8 & \\
\hline & & & & & & & & & \multicolumn{3}{|c|}{100} & \\
\hline
\end{tabular}

Sumber: Hasil pengolahan data oleh peneliti

Tabel 9. Perhitungan Kesesuaian/Ketidaksesuaian Karakteristik Pengasuhan dengan Faktor Sukses Kritis dan Peluang Pengasuhan PT. Pupuk Indonesia Energi

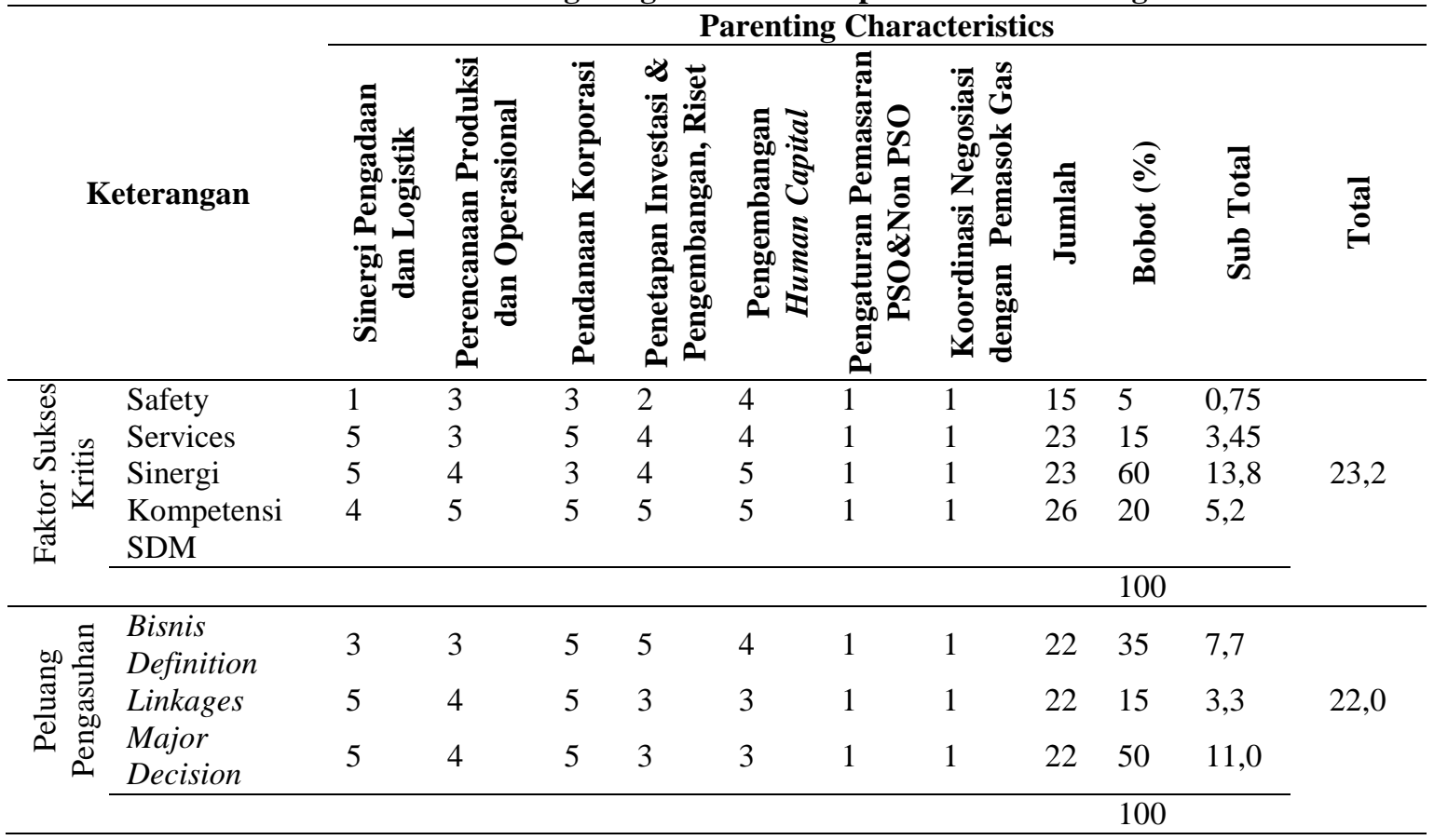


Tabel 10. Perhitungan Kesesuaian/Ketidaksesuaian Karakteristik Pengasuhan dengan Faktor Sukses Kritis dan Peluang Pengasuhan PT. Pupuk Indonesia Pangan

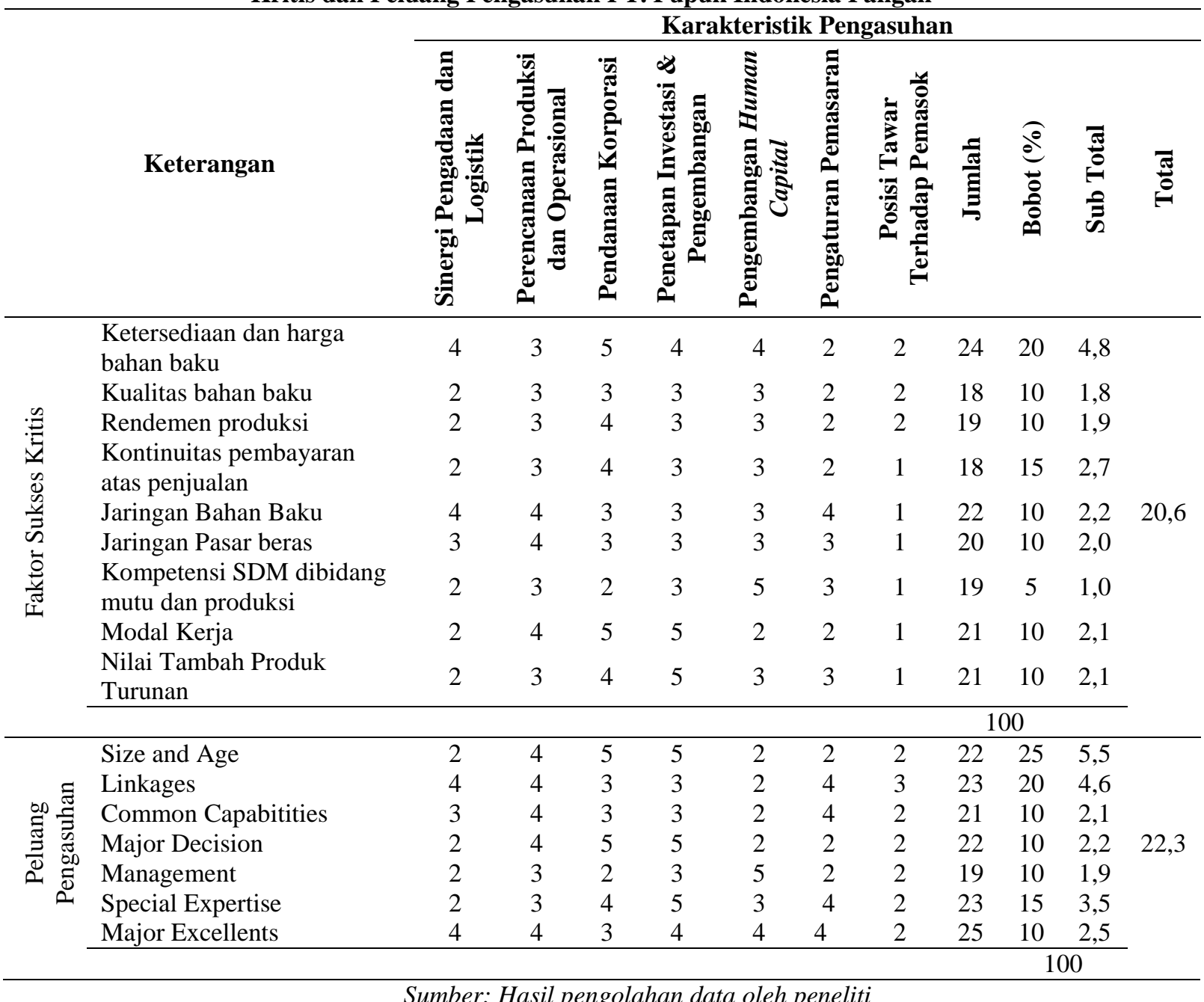

Tabel 11 menunjukkan kompilasi nilai kesesuaian/ketidaksesuaian karakteristik pengasuhan dengan faktor sukses kritis dan peluang pengasuhan setiap perusahaan anak yang kemudian menjadi koordinat pada matriks kesesuaian pengasuhan (Gambar 2). Tabel 11 juga menunjukkan persentase kontribusi pendapatan setiap perusahaan anak yang diterjemahkan dalam bentuk ukuran lingkaran dalam matriks kesesuaian pengasuhan.

Tabel 11. Kompilasi Nilai Kesesuaian/Ketidaksesuaian dan Kontribusi Pendapatan Seluruh Perusahaan Anak

\begin{tabular}{ccccc}
\hline NO & NAMA & SUMBU X & SUMBU Y & KONTRIBUSI PENDAPATAN (\%) \\
\hline 1 & PKG & 35 & 34.3 & 38 \\
2 & PSP & 34.7 & 34.4 & 7 \\
3 & PKC & 34.5 & 33.9 & 15 \\
4 & PKT & 34.4 & 35 & 26 \\
5 & OIM & 31.8 & 32.8 & 4 \\
6 & PLOG & 25.49 & 24.4 & 0.4 \\
7 & PIP & 22.3 & 20.6 & 0.1 \\
8 & PIE & 22 & 23.2 & 0.5 \\
9 & REK & 18.7 & 18.3 & 7 \\
10 & ME & 17.6 & 17.8 & 2 \\
\hline \multicolumn{5}{c}{ Sumber: Hasil pengolahan data oleh peneliti }
\end{tabular}




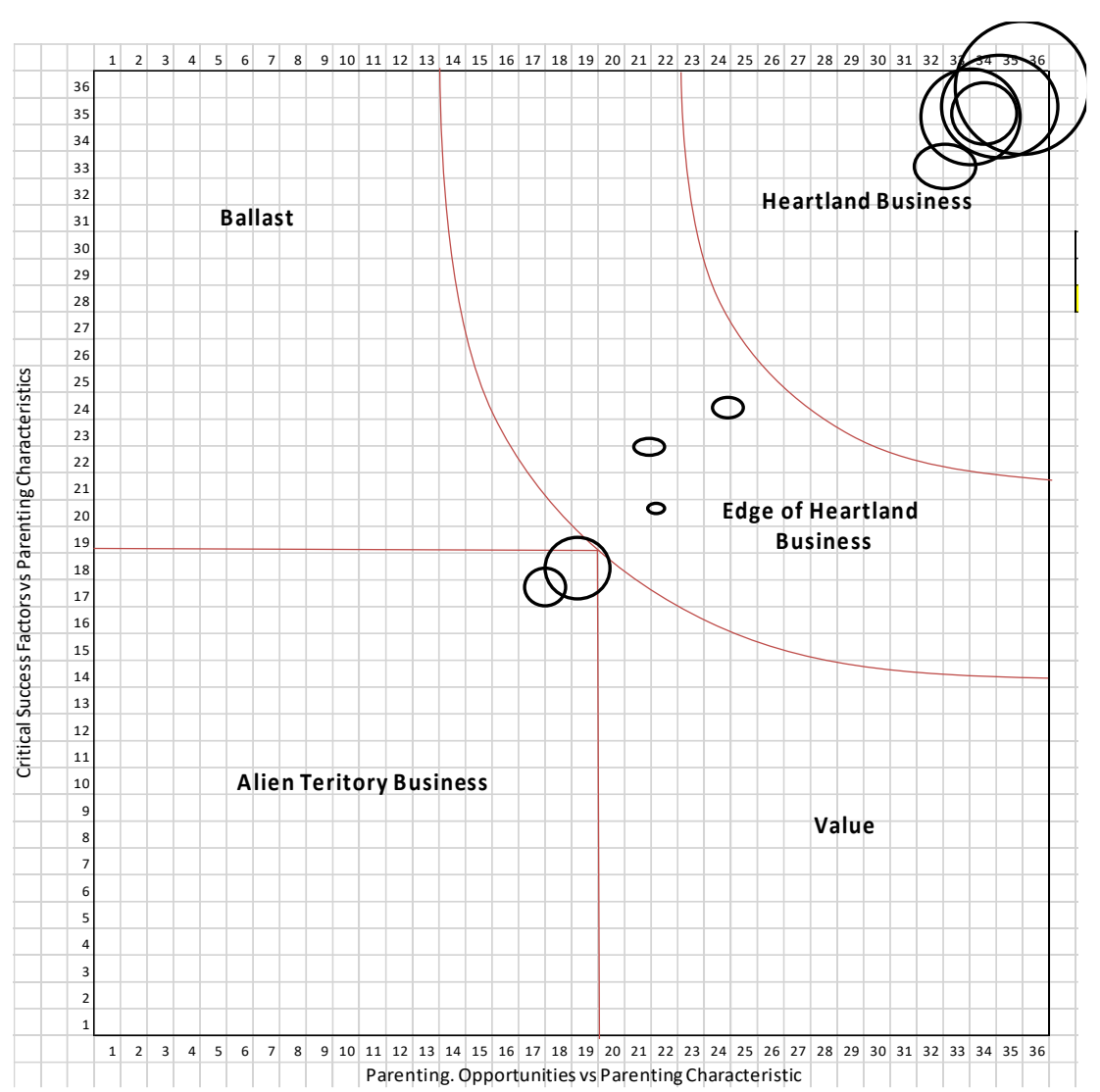

Gambar 2. Matriks Kesesuain Pengasuhan PT. Pupuk Indonesia (Persero) Sumber: Hasil pengolahan data oleh peneliti

Berdasarkan hasil pemetaan anak perusahaan dalam matriks kesesuaian pengasuhan (Gambar 2), kelompok usaha Industri Pupuk dan Bahan Kimia masuk dalam kategori heartland business maka strategi yang diberikan oleh PI berupa linkage influence yaitu optimalisasi sinergi dari unit bisnisnya untuk mendapatkan nilai yang lebih tinggi dibandingkan perusahaan induk yang sejenis. PI juga bisa melakukan corporate development dimana perusahaan induk melakukan kreasi nilai melalui penetapan bisnis baru yang masih dalam kompetensi intinya (corporate development).

PT Rekayasa Industri masuk dalam kategori alien territory business, demikian pula dengan PT Mega Eltra. Menurut Campbell, dkk. (1995, 2014) serta studi dari Ciabuschi, dkk. (2016), Munir (2017), dan Fernandez \& Montoya (2018) perusahaan kategori alien territory business mempunyai potensi menghancurkan nilai kelompok bisnis. Hal ini disebabkan karena adanya ketidaksesuaian antara karakteristik induk, dalam hal kompetensi, kualitas jejaring, dan kurva belajar, dengan faktor sukses kritis perusahaan anak. Dari sisi kinerja PT Rekaya Industri dan PT Mega Eltra mengalami kerugian yang cukup besar sehingga mengurangi laba konsolidasi PT Pupuk Indonesia (Persero). Maka strategi yang sebaiknya diambil oleh PI sebagai induk perusahaan selain melakukan restrukturisasi usaha adalah melakukan linkage influence yaitu mempengaruhi seluruh anak perusahaan agar menggunakan jasa EPC yang dimiliki PT Rekayasa Industri dan menggunakan jasa pemasaran yang dimiliki PT Mega Eltra melalui sinergi antar perusahaan dalam kelompok usaha PT Pupuk Indonesia (Persero). 
Selanjutnya PT Pupuk Indonesia Logistik dan PT Pupuk Indonesia Pangan keduanya termasuk dalam kategori edge of heartland business, dan dengan mempertimbangkan posisi perusahaan yang masih baru berdiri maka strategi yang dilakukan oleh PI berupa stand-alone influence dimana PI selaku induk perusahaaan mempengaruhi strategi bisnis kedua perusahaan anak tersebut. Jadi kreasi nilai disini terjadi karena induk perusahaan menerapkan pengendalian yang ketat atas kinerja anak perusahaan yang diberi target atas laba. Hal ini berbeda dengan PT Pupuk Indonesia Energi, walau juga baru didirkan dan berada dalam kategori edge of heartland business, namun pengasuhan yang dilakukan adalah linkage influence. PI mempengaruhi perusahan-perusahaan anak yang dimilikinya dengan berusaha mengaitkan kerjasama dan sinergi diantara unit bisnis yang dapat dikembangkan dengan cara peningkatan skala ekonomis melalui jasa utilitas dalam operasi pabrik seperti dukungan energi listrik dan gas uap.

\section{KESIMPULAN DAN SARAN}

Penelitian ini menunjukkan bahwa perusahaan-perusahaan anak dalam kelompok bisnis inti atau pupuk diasuh dengan menggunakan pola corporate development dan linkage influence. Kelompok bisnis yang tidak sesuai dengan karakteristik pengasuhan induk perusahaan, diasuh dengan pola linkage influence. Sementara perusahaan anak yang baru didirkan, diasuh dengan stand alone influence, kecuali PT. Pupuk Indonesia Energi yang diasuh dengan pola linkage influence karena sifat bisnisnya.

Studi ini membutuhkan analisis tingkat kesesuaian yang lebih mendalam dan menyeluruh terhadap seluruh anak-anak perusahaan karena penggunaan matriks kesesuaian pengasuhan masih memiliki keterbatasan yang berasal dari subyektivitas yang tinggi dari peneiti yang kebetulan adalah eksekutif di PI. Diperlukan pendekatan yang lebih terukur untuk dapat memetakan perusahaanperusahaan anak, misalnya dengan mengkombinasikan studi ini dengan matriks-matriks portofolio bisnis lainnya. 


\section{DAFTAR PUSTAKA}

Afza, T., C. Slahudin, dan M. S. Nazir. (2008). Diversification and corporate performance: an evaluation of Pakistani firms. South Asian Journal of Management 15(3):7-18.

Basu, N. (2010). Trends in corporate diversification. Financial Markets and Portfolio Management 24(1): 87-102.

Bowman, E. H. dan Helfart, C. E. (2001). Does Corporate Strategy Matter ?. Strategic Management Journal, 22: 1 - 23

Campbell, A., M. Goold, dan M. Alexander. (1995). Corporate strategy: The quest for parenting advantage. Harvard Business Review (March-April): 120-132.

(2014). Strategy for the corporate level: Where to invest, Where to cut back, How to growth organization wite multiple divestation. San Francisco: Jossey-Bass.

Ciabuschi, F., M. Forsgren, dan O. Martin. (2016). Value creation at the subsidiary level: testing the MNC headquarters parenting advantage logic. Long Range Planning 50(1), 48-62.

Collis, D., D. Young, dan M. Goold. (2012). The size and composition of corporate headquarters in multinational companies: empirical evidence. Journal of International Management 18(3): $260-275$.

Fernández, F.A., dan Montoya, L.M.R. (2018). Multi-business companies: The Leonisa case. Cuadernos De Administración, 34(60), 81 - 95.

Goold, M., Campbell, A., dan Alexander, M. (1998). Corporate strategy and parenting theory. Long Range Planning, 31(2), 308-314.

Kim, K. (2018). Matchmaking: Establishment of state-owned holding companies in Indonesia. Asia \& the Pacific Policy Studies, 5(2), 313-330.

Kishita, T., dan Hayashi, N. (2019). Parental control on subsidiaries in corporate groups with a pure Holding Company. Review of Integrative Business and Economics Research, 8(3), 43

Kruehler, M., Pidun, U., dan Rubner, H. (2012). How to assess the corporate parenting strategy? A conceptual answer. The Journal of Business Strategy, 33(4), 4-17. 
Munir, N. S. (2017). Kesesuaian Pengasuhan Perusahaan Multi Bisnis: Studi Kasus Kelompok Media Group. Jurnal Ekonomi dan Bisnis 20(2): 1979 - 6471.

Nell, P.C., dan Ambos, B. (2013) Parenting advantage in the MNC: An embeddedness perspective on the value added by headquarters. Strategic Management Journal, 34 (9), 1086-1103.

Pidun, U., Richter, A., Schommer, M., dan Karna, A. (2019). A new playbook for diversified companies. MIT Sloan Management Review, 60(2), 1.

Porter, M. (1998). Competitive Strategy: Techniques for analyzing industries and competitors. New York: Free Press.

Pranoto, T. (2017) Holding Company BUMN: Konsep, implementasi dan benchmarking. Jakarta: Lembaga Management Fakultas Ekonomi dan Bisnis Universitas Indonesia.

Rawley, E., Godart, F. dan Shipilov, A. (2018). How and when do conglomerates influence the creativity of their subsidiaries?. Strategic Management Journal 39(9):2417-2438

Sekaran, U. dan Bougie, R. (2016). Research Methods For Business: A Skill Building Approach $7^{\text {th }}$ Edition. West Sussex: John Wiley \& Sons.

Wheelen, T.R.,Hunger, D. J., Hoffman, A. N., dan Bamford, C. (2014), Concepts in strategic management and business policy $14^{\text {th }}$ Edition. Engleword Cliffs, NJ : Prentice-Hall,. 